\title{
Avoiding economic crashes on China's road to prosperity
}

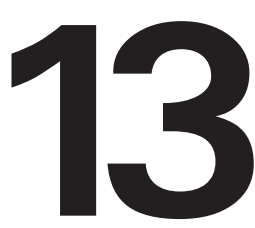

Wing Thye Woo

\section{Introduction}

There is a long tradition of predictions of gloom and doom among China economists. For example, in the mid 1990s, Nicholas Lardy (1998) of the Peterson Institute for International Economics started highlighting the de facto insolvency of the Chinese banking system with the implication that a bank run leading to financial-sector ruin was a strong possibility in the medium term. The twenty-first century began with the claim by Gordon Chang (2001) that China's imminent accession to the World Trade Organisation (WTO) would cause such widespread unemployment within China's already alienated population that the country's economic and political systems would collapse.

These two dire predictions have turned out to be wrong. China, in fact, accelerated its annual gross domestic product (GDP) growth to double-digit rates after 2001. Lardy was wrong because, while the banks were indeed bankrupt, the Chinese government that owned them was not bankrupt and could afford to bail out the banks when necessary. The fiscal strength of the government made it irrational for depositors to contemplate a bank run. Chang was wrong because WTO membership quickened the pace of job creation in China by greatly increasing the volume of foreign direct investment (FDI) inflow. WTO membership made China more attractive to FDI because it guaranteed the access of Chinese goods to the US market by eliminating the need for China to received most-favoured nation (MFN) status annually from the US Congress (McKibbin and Woo 2003).

The fact that the doomsayers have been wrong so far does not mean that their dire predictions are guaranteed not to happen in the future. It also does not mean that gloom and doom can be ruled out because the doomsayers could simply have been wrong in their specific identifications of where they would come from. This chapter is, first, an assessment of some of the obstacles that China could stumble into on its development path; and, second, a proposal for how these obstacles could be overcome. 


\section{The rocky road to prosperity}

The tradition of forecasting gloom and doom for China is quite surprising given China's economic performance in the past 30 years and, indeed, it is becoming more common to hear glowingly optimistic assessments of China's future than dismissively pessimistic ones. For example, Jim O'Neill et al. (2005) of Goldman Sachs have predicted that China's GDP will surpass that of the United States in 2040 even after assuming that China's GDP growth rate will slow steadily from its average annual rate of 10 per cent during 1979-2005 to 3.8 per cent during $2030-40 .^{1}$

A good guide to how one should regard the new optimism and the traditional pessimism can be found in the discussions of the Sixth Plenum of the Sixteenth Central Committee of the Communist Party of China (CPC) in October 2006. The sixth plenum passed a resolution to commit the CPC to establish a harmonious society by 2020. The obvious implication is that the present major social, economic and political trends within China might not lead to a harmonious society or, at least, not rapidly enough.

Among the disharmonious features mentioned in the 'resolutions of the CPC Central Committee on major issues regarding the building of a harmonious socialist society' were serious imbalances in social and economic development across (and within each of) China's 31 provinces; worsening population and environmental problems; grossly inadequate social safety nets and healthcare systems; and serious corruption. The harmonious socialist society would encompass a democratic society under the rule of law; a society based on equality and justice; an honest and caring society; a stable, vigorous and orderly society; and a society in which humans live in harmony with nature.

China's economy during the past three decades can be likened to a speeding car. The CPC leadership in 2006 saw that the car could crash in the future because there were several high-probability failures that might occur and cause economic collapse. To be specific, there are three classes of failures that could occur: hardware failure, software failure and power supply failure.

A hardware failure refers to the breakdown of an economic mechanism-a development that is analogous to the collapse of the chassis of a car. Probable hardware failures include a banking crisis that causes a credit crunch, a budget crisis that necessitates reductions in important infrastructure and social

1 For a review of the debate on how to interpret China's high growth in 1978-2000 and why China - unlike the economies of the former Soviet bloc-did not experience a recession when it made the switch from a centrally planned economy to a market economy, see Sachs and Woo (2000) and Woo (2001). 
expenditure (and possibly generates high inflation and balance-of-payments difficulties as well) and a serious slowdown in productivity growth from the accumulation of micro-inefficiencies created by state intervention.

A software failure refers to a flaw in governance that creates frequent widespread social disorders that disrupt economy-wide production and discourage private investment. This situation is similar to a car crash that results from a fight among the people inside the speeding car. Software failures could come from the present high-growth strategy creating enough inequality and corruption to generate severe social unrest, and from the State not being responsive enough to rising social expectations, hence causing social and economic disorder.

A power supply failure refers to the economy being unable to move forward because it hits either a natural limit or an externally imposed limit - a situation that is akin to the car running out of fuel (a natural limit) or into a roadblock erected by foreigners (an externally imposed constraint). Examples of power supply failures are an environmental collapse and a collapse in China's exports because of a trade war.

There are many events within each type of failure that could make China's high growth unsustainable is beyond the scope of this chapter. We limit the discussion here to those that seem most likely in June 2010.

\section{Potential hardware failure}

China will face two potential hardware failures in the aftermath of the global financial crisis: a weakening of the fiscal position and a slowdown in productivity growth. To see the source of our concern, we have to recall, first, the nature of the global financial crisis and the manner in which it impacted on China; and second, the kind of economic mechanisms that were used to generate the stunning 8.7 per cent GDP growth rate in 2009.

The global financial crisis burst onto the world scene on 15 September 2008 when investment bank Lehman Brothers filed for bankruptcy. This action sparked a wholesale flight to liquidity that caused a meltdown of financial markets globally. This widening financial crash, in turn, became a negative feedback loop to the level of aggregate income. GDP growth (year-on-year) turned negative in the fourth quarter of 2008 in the United States ( -1.9 per cent) and the United Kingdom (-2.1 per cent).

This abrupt decline in GDP of the major advanced economies translated into a large, abrupt negative external shock to China that had two components: 
a negative export shock and a negative inward FDI shock. ${ }^{2}$ This prolonged contractionary external impulse hit China at a time when its economy was already slowing from the tightening of monetary policy that was implemented immediately after the conclusion of the seventeenth CPC congress in October 2007. In the run-up to the party congress, easy monetary policy had steadily boosted GDP growth from 10.4 per cent in 2005 to 11.6 per cent in 2006 and 13 per cent in 2007. GDP growth, which had been brought down by tighter monetary policy to 10.4 per cent in the second quarter of 2008 , fell to 9.6 per cent in the fourth quarter of 2008, and then further to 6.1 per cent in the first quarter of 2009, under the additional squeeze from the large drop-off in export and foreign investment.

The Chinese government responded with very aggressive fiscal and monetary policies to offset the external deflationary policies. It announced in early November 2008 that a fiscal stimulus of RMB4 trillion would be undertaken in 2009-10 - an annual stimulus of about 7 per cent of GDP. Monetary easing has been even more dramatic, with broad money (M2) increased by 28 per cent in 2009.

While consumer price index (CPI) inflation in 2009 was reassuringly low at -0.7 per cent, 'land prices...doubled in 2009 on a nationwide basis' ('China tells banks to restrict loans to local governments', The New York Times, 25 February 2010). The value of residential property transactions in 2009 was 80 per cent higher than in 2008 ('Market defies fear of real estate bubble in China', The New York Times, 4 March 2010). ${ }^{3}$ The first quarter of 2010 saw even more rapid increases in land prices, especially in the major coastal cities. ${ }^{4}$ In mid April 2010, the government sought to stabilise property prices by imposing restrictions on mortgage applications to buy second and third homes.

The roaring real estate market and the use of non-market means (for example, bans on purchases) to tame it are symptoms of some deep economic problems that China has to address in order to sustain growth over the long run. Specifically, the real estate boom is part of a generalised investment boom unleashed by the RMB4 trillion stimulus program implemented since November 2008. The fact that the central government would fund only one-third of the proposed expenditure might prompt one to think of the stimulus program as a work agenda for the government to create the incentives to induce investment to

2 On a year-on-year basis, the growth rate of exports turned abruptly negative ( -2.2 per cent) in 2008 (11 months) and remained negative through 2009 (11 months). The growth rate of FDI also turned abruptly negative in 2008 (11 months) - to -36 per cent from 35 per cent in 2008 (10 months); remained negative through 2009 (seven months); and recovered to historically low levels in 2009 (eight months) to 2010 (four months).

3 The article also reported that some duplexes in Shanghai were selling for US $\$ 45$ million each.

4 In 2009, land prices had gone up 200 per cent in Shanghai, 400 per cent in Guangzhou and 876 per cent in Wenzhou ('China: no one home', Financial Times, 21 February 2010). 
reach the stated level, but such an interpretation would be wrong. The stimulus should be properly understood as permission by the central government to allow additional investments up to the stated level.

This different understanding is based on the reality that a large part of China's economy is still state controlled ${ }^{5}$ and that this segment pursues other objectives besides the ideal of profit maximisation. Because state-controlled enterprises (SCEs) are usually bailed out when their investments turn out to be based on over-optimistic projections or are derailed by bad luck, the outcome is the well-known interest-inelastic phenomenon of a 'thirst for investment' by SCEs and local governments. The state-appointed SCE manager is always in favour of expanding the scale and range of the operation of the SCE because it yields three major benefits to him or her: higher likelihood of promotion based on the proven ability to handle bigger things; greater patronage power to build a political base; and more resources that could potentially be diverted for personal gain. Similarly, local government leaders also share the enthusiasm of SCE managers for economic growth in their administrative regions for the same three reasons.

Whenever the state-controlled banks (SCBs), which dominate China's financial sector, extend loans to accommodate the high demand for investment loans by SCEs and local governments, a 'liquidity tango' is generated. The inevitable outcome of a protracted liquidity tango is high inflation followed by nonperforming loans (NPLs). ${ }^{6}$ The notable period when such liquidity tangos were rare was 1996-2001 when Zhu Rongji was prepared to punish the managers of SCBs severely for the appearance of new NPLs. The key is that whenever a SCB manager feels they are operating under a soft-budget constraint, they extend loans readily because a scaling-up of lending brings the three benefits mentioned previously.

At present, the central government has two lines of institutional defence to prevent the liquidity tango from getting out of hand in China's partially reformed economy. The first line is that all large projects need the approval of the National Development and Reform Commission (NDRC; formerly, the State Planning Commission). The second line is that all banks are assigned credit quotas.

So, when Premier Wen Jiabao approved the stimulus program and covered only one-third of its cost, he was giving permission: 1) to the SCEs and local governments to invest more in order to offset the spending slump in the private

\footnotetext{
5 State-controlled firms include state-owned firms and publicly listed firms in which the State and its intermediaries hold the controlling share.

6 See Woo (2006) for a more detailed discussion of how the frequent rescue of state firms (also known as the soft-budget practices of the government) has made the economy inflation prone since economic decentralisation began in 1978 .
} 
sector; and 2) to the SCBs to extend the necessary loans to fund the approved projects. Herein lies the mechanism for the success of the stimulus program: the use of capacity-maximising state-controlled production and financial units to boost aggregate demand. Because the SCEs and SCBs are implementing a stateassigned mission, their managers cannot rightly be held responsible should the assigned projects turn out to be financial busts in the future.

Not surprisingly, the public media carries occasional anecdotes about new investments in industries plagued by overcapacity (for example, steel, cement and aluminium), trophy investments (for example, grand town centres, highspeed rail and stately administrative buildings) and spontaneous privatisation of project funds (for example, massive purchases of cars by state bodies). ${ }^{7}$ Another common concern about China's stimulus program was that the SCBs were channelling the flood of liquidity to the SCEs and neglecting the increased financing needs of the private sector brought on by the global financial crisis. Pressed for working capital, two well-known large private companies, Rizhao (a steel firm) and Mengniu (a dairy), agreed to be acquired by their state-owned counterparts.

While it is clear that China's massive macro-stimulus program has been successful in warding off deflation from the negative external shocks, we see this program as creating two potential hardware failures in the future.

The first is a weakening of the future fiscal position of the State. Many of the industrial and infrastructure investments in 2009 were undertaken by the 8000 local investment companies established by local governments. It has been estimated that the loans of these investment vehicles amounted to 51 per cent of GDP in 2009. ${ }^{8}$ (The present debt of the central government amounts to 20 per cent of GDP.) Adding in the large loans to the SCEs, the recent stimulus program has the potential of generating a huge number of NPLs. It is important to see that NPLs are not just a financial-sector problem; they are a fiscal problem. The US and UK bailouts of their financial systems in 2008-09 make this point most clearly.

Given China's history of liquidity tangos, it is reasonable to worry that most of the bank loans to the stimulus program will end up as NPLs. ${ }^{9}$ The resulting

\footnotetext{
7 See, for example, Forsythe (2009); 'China: no one home', Financial Times, 21 February 2010; 'China audit finds misuse of funds tied to stimulus', Financial Chronicle, 29 December 2009, <http://www.mydigitalfc. com/news/china-audit-finds-misuse-funds-tied-stimulus-821>; and 'China boosts auditors' power as stimulus package spending prompts corruption concerns', People's Daily, 21 February 2010, <http://english. peopledaily.com.cn/90001/90776/90785/6898354.html>

8 The 51 per cent figure is from combining information in Shih (2010), who reported the debt of the central government to be 20 per cent of GDP, with information in the Financial Times ('China warned of growing "land loan" threat', 28 March 2010) that reported the combined figure was 71 per cent.

9 Some observers have pointed out that the NPL ratio has stayed low since the second round of recapitalisation in 2003 and, hence, have claimed that the SCBs have improved their internal incentives and risk-assessment
} 
financial crisis would cause China to crash much like the United States and the United Kingdom did in 2009 unless the Chinese government stepped in againas it did in the 1998-2003 period to recapitalise the banks. Such a large-scale recapitalisation would inevitably mean that state expenditure in other categories would have to be reduced. ${ }^{10}$

The second potential hardware failure that could result from the 2009-10 macrostimulus program is a slowdown in the productivity growth of the economy. Unless the 2008-10 expansion of the state sector (sometimes occurring the expense of the private sector) is balanced by a larger expansion in the private sector, the post-1949 economic history of China does not give ground for optimism that Premier Wen's way of imparting the needed boost to capacity utilisation during the global financial crisis will not become a drag on future productivity growth ('Communist Party needs to loosen its grip on China', The New York Times, 2 March 2010). ${ }^{11}$

\section{Potential software failure}

The satisfactory functioning of a market economy requires a wide array of regulatory institutions that ranges from straightforward law-and-order administration to complicated legal adjudication. China's strategy of incremental reform combined with the fact that institution building is a time-consuming process means that many of its regulatory institutions are either absent or ineffective. The result has been governance failure on many fronts, with the most well-known recent ones being violations of the welfare of consumers and workers.

There have been significant regulatory failures in keeping China's food supply and pharmaceutical products safe. The misuse of chemicals to lower production costs has resulted in the addition of poisonous substitutes to toothpaste ('China investigates contaminated toothpaste', The New York Times, 22 May 2007; 'China prohibits poisonous industrial solvent in toothpaste', The New York Times, 12 July 2007), cough medicine ('From China to Panama, a trail of poisoned medicine', The New York Times, 6 May 2007) and animal feed ('Filler in animal feed is open secret in China', The New York Times, 20 April 2007; 'Another chemical emerges in pet food case', The New York Times, 9 May 2007);

\footnotetext{
ability so much that large NPL ratios are a thing of the past. We, however, think that it is premature to pronounce victory on state-owned bank (SOB) reforms because the 2003-09 period has been one of high growth.

10 See Tong and Woo (2006) for an analytical discussion of the undermining of fiscal stability by the constant recapitalisation of SCBs.

11 This debate over the growth of the state firms at the expense of private ones is conducted over the heading of 'guojin mintui' (the state sector advances, and the private sector withdraws).
} 
the application of lead paint to children's toys ('As more toys are recalled, the trail ends in China', The New York Times, 19 June 2007; 'Train wreck', The New York Times, 19 June 2007; 'Fisher-Price recalls 1.5m China-made toys', Financial Times, 2 August 2007); ${ }^{12}$ and the overuse of antifungals and antibacterials in fish farming ('FDA curbs sale of 5 seafoods farmed in China', The New York Times, 29 June 2007; 'A slippery, writhing trade dispute', The New York Times, 3 July 2007). Dereliction of duty by government officials is the fundamental reason for such governance failures. The most well-known recent case was the conviction of Zheng Xiaoyu, the former director of China's food and drug safety agency, for accepting bribes to approve production licences for pharmaceutical and food companies ('Ex-chief of China food and drug unit sentenced to death for graft', The New York Times, 30 May 2007; 'For 2 children, ban of a drug came too late', The New York Times, 13 July 2007).

There have also been significant regulatory failures in the treatment of labour, especially in the areas of occupational safety and wage payments. One of the most recent horrifying accounts involved the forced labour of kidnapped children in the brick kilns of Shanxi and Henan Provinces ('China to investigate into "slave labour" incident', China Daily, 16 June 2007). ${ }^{13}$ The official China Daily reported that 'as many as 1,000 children may have been sold into slave labour in central China' ('China brickwork slave children may number 1,000', China Daily, 15 June 2007). A parent visiting the brick kilns in her quest to find her son found that the local police were not only unwilling to help but demanded bribes ('Reports of forced labour unsettle China', The New York Times, 16 June 2007). In one case, the son of the village party secretary owned the brick kiln ('5 Chinese arrested in enslavement case', The New York Times, 18 June 2007).

Perhaps the two most dismaying revelations from the news reports on the brick kiln slavery are that this sad state of affairs has been going on for a decade ${ }^{14}$ and the 'forced labour and sexual exploitation have increased as the trend in human trafficking in China has taken a turn for the worst' ('More forced into prostitution, labour', China Daily, 27 July 2007). Yin Jianzhong, the senior official at the Ministry of Public Security who identified the worsening trend in human trafficking in China, recognised a reason for the negative development to be 'the loopholes in the legal and labour systems... [Specifically,] the Criminal Law on human trafficking protects women and children only and leaves out grownup and teen males. It doesn't have provisions for punishing those trafficking

12 The first article also reported the recall of a ghoulish fake eyeball that was filled with kerosene and of an infant's wrist rattle that presented a choking hazard.

13 The New York Times ('China slave scandal brings resignation calls', 18 June 2007) reported that '[t]he workers endured prison-like confinement with fierce dogs and beatings...Released workers were shown on television with festering wounds and emaciated bodies.'

14 This point was made by the popular tabloid Southern Metropolis Daily; see The New York Times ('China slave scandal brings resignation calls', 18 June 2007). 
people for forced labour or prostitution' ('More forced into prostitution, labour', China Daily, 27 July 2007). The fact that such legal loopholes exist supports our contention that the main cause of the governance failures in China is the 'dereliction of duty by government officials'. ${ }^{15}$

Inadequate institutions of governance are not, however, the only cause of social tensions in China. The present economic development strategy, despite its ability to generate high growth, also generates high social tensions because, in the past 10 years, it has failed to reduce extreme poverty and to improve significantly the rural-urban and regional income distributions (Woo et al. 2004; Démurger et al. 2002). In an Asian Development Bank (ADB 2007) study of income inequality in 22 Asian countries, in 2004, only Nepal had a Gini coefficient (47.3) that was higher than China's (47.3). Meanwhile, in 2004, China's income ratio of the richest 20 per cent to the poorest 20 per cent (11.4) of the population was the highest in Asia - significantly higher than the next highest income ratio (9.5 for Nepal). China is probably the most unequal country in Asia today.

In the first phase of China's economic development, the provision of more jobs was enough to lower poverty significantly. At present, however, many of the people who are still poor require more than just job opportunities. They first need an infusion of assistance (for example, empowering them with human capital through education and health interventions) in order to be able to take up these job opportunities. Effective governance for equitable growth has now become even more challenging, so the probability of improving social harmony has been diminished.

Furthermore, the present mode of economic development also generates immense opportunities for embezzlement of state assets, seizure of farmlands for industrial development and corruption because of the absence of effective mechanisms to supervise government employees (Woo 2001). These features certainly make social harmony hard to sustain.

The data on social unrest are consistent with the hypothesis of rising social disharmony. First, the incidence of public disorder - labelled 'social incidents' has risen steadily from 8700 in 1993 to 32500 in 1999, and then to 74000 in 2004. Second, the average number of people involved in mass incidents has also risen greatly-from eight in 1993 to 50 in 2004.

\footnotetext{
15 This point was made by the Shanxi Governor, Yu Youjun, who said: 'For a long time, relevant government departments did little to regulate rural workshops, small coal mines and small factories, and they are basically out of control and are not being supervised... The dereliction of duty by civil servants and the corruption of individuals have made it possible for illegal labour to exist, particularly the abductions of migrant workers, and forced labour of children and mentally disabled people.' See 'Fears linger over child slaves at kilns', South China Morning Post, 23 June 2007.
} 
Clearly, the number of mass incidents would have been lower if China had better governance. There would have been more pre-emptive efforts at conflict mediation by the government and less abuse of power by government officials if the government's actions had been monitored closely by independent mechanisms - and also if the government had been held more accountable for its performance.

\section{Power supply failure}

The two most probable power supply failures that China faces are trade protectionism and environmental crises. While we think that trade protectionism is the likelier of the two to cause growth failure in the medium run, we will limit ourselves to some brief remarks on this type of power supply failure just before concluding the chapter because we have analysed this issue at length in Woo and Xiao (2007) and Woo (2008).

The present mode of economic development has given China the dirtiest air in the world, is polluting more and more of its water resources and is, possibly, changing the climate patterns within China. The reality is that the CPC's new objective of living in harmony with nature is not a choice because the Maoist adage of 'man conquering nature' is just as unrealistic as creating prosperity through central planning. There is no doubt that China's rapid growth in the past two decades has done substantial damage to the environment (Economy 2004).

Water shortages appear to pose the most immediate environmental threat to China's continued high growth. ${ }^{16}$ Presently, China uses $67-75$ per cent of the 800-900 billion cubic metres of water available annually, and present trends in water consumption project the usage rate in 2030 to be $78-100$ per cent ('Top official warns of looming water crisis', South China Morning Post, 7 November 2006). The present water situation is already fairly critical because of the uneven distribution of water and the lower than average rainfall in the past 15 years. Right now, about '400 of China's 660 cities face water shortages, with 110 of them severely short' ('China may be left high and dry', The Straits Times, 3 January 2004). ${ }^{17}$

The extended period of semi-drought in northern China combined with economic and population growth have caused more and more water to be pumped from

16 Air pollution is also a serious problem. Of the 20 cities in the world identified by the World Bank as having the dirtiest air, 16 are in China. It is shocking that lead and mercury poisoning are more common than expected; see 'China's economic miracle contains mercuric threat', Financial Times, 18 December 2004; and 'A poison spreads amid China's boom', The Wall Street Journal, 30 September 2006.

17 The shortage is reported to be most acute in Taiyuan in Shanxi and Tianjin (Becker 2003). 
the aquifers, leading the water table to drop 3-6 metres a year ('Northern cities sinking as water table falls', South China Morning Post, 11 August 2001; Becker 2003). A study using measurements from satellites has established that the part of China north of the thirty-sixth parallel has been 'sinking at the rate of 2 mm a year' ('Northern China sinking... as the south rises', The Straits Times, 18 March 2002). ${ }^{18}$ Specifically, 'Shanghai, Tianjin, and Taiyuan are the worst hit in China, with each sinking more than two metres (6.6 feet) since the early 1990s' ('Chinese cities, including Olympic host Beijing, slowly sinking', Agence FrancePresse, 23 July 2004). The overall water situation in northern China is reflected in the fate of the Yellow River, 'which started drying up every few years from 1972, did so for increasing periods of time over longer distances in the 1990s until 1997, when it dried up for almost the entire year over a stretch of several hundred kilometres' ('China may be left high and dry', The Straits Times, 3 January 2004).

Water shortages and the increasing pollution of water are not the only serious environmental threats to the economy of northern China ${ }^{19}$. The desert is expanding (possibly, at an accelerating pace) and humans appear to be the chief culprits. The State Forestry Administration reported that 28 per cent of the country's landmass was affected by desertification in 1999 and 37 per cent was affected by soil erosion. The report identified about 65 per cent of the desert as having been created by 'over-cultivation, overgrazing, deforestation and poor irrigation practices' ('Quarter of land now desert-and man mostly to blame', South China Morning Post, 30 January 2002). One direct upshot is a great increase in the frequency of major sandstorms ${ }^{20}$ that play 'havoc with aviation in northern China for weeks, cripples high-tech manufacturing and worsens respiratory problems as far downstream as Japan, the Korean peninsula and even the western United States' ('Billions of trees planted, and nary a dent in the desert', The New York Times, 11 April 2004). In the assessment of Chen Lai, Vice-Minister of Water Resources: 'It will take nearly half a century for China to control the eroded land and rehabilitate their damaged ecosystems in accordance with China's present erosion-control capabilities' ('Quarter of land now desert - and man mostly to blame', South China Morning Post, 30 January 2002).

\footnotetext{
18 According to Becker (2003): 'Some 60 per cent of the land in Tianjin municipality is plagued by subsistence.'

19 Examples of reports about serious water pollution include: 'Main rivers facing a "pollution crisis"', South China Morning Post, 6 June 2003; 'Booming cities polluting scarce water supplies', The Straits Times, 18 September 2003; 'Rivers run black, and Chinese die of cancer', The New York Times, 12 September 2004; “'Cancer villages" pay heavy price for economic progress', South China Morning Post, 8 May 2006; and 'Rules ignored, toxic sludge sinks Chinese village', The New York Times, 4 September 2006.

20 The number of major sandstorms in China was five in the period 1950-59, eight in 1960-69, 13 in 197079, 14 in 1980-89, 23 in 1990-99, 14 in 2000, 26 in 2001, 16 in 2002 and 11 in 2003, according to Yin Pumin ('Sands of time running out: desertification continues to swallow up "healthy" land at an alarming rate', Beijing Review, 16 June 2005).
} 
While northern China has been getting drier and experiencing desertification, nature - as if in compensation (or in mockery) - has been dousing southern China with heavier rains, causing heavy floods that have brought considerable deaths and property damage almost every summer since $1998 .^{21}$ The sad possibility is that the northern droughts and southern floods might not be independent events but a combination caused by pollution that originates in China. We will have more to say about this possibility later.

Clearly, without water, growth cannot endure. In response to this, the government began implementation in 2002 of Mao Zedong's 1952 proposal for three canals to be built to take water from the south to the north: an eastern coastal canal from Jiangsu to Shandong and Tianjin, a central canal from Hubei to Beijing and Tianjin, and a western route from Tibet to the north-western provinces ('Ambitious canal network aims to meet growing needs', South China Morning Post, 27 November 2002). Construction of the eastern canal (to be built on a part of the existing Grand Canal) started in 2002 and of the central canal in 2003. Work on the western canal is scheduled to begin in 2010 on completion of the first stage of the central canal.

This massive construction project will be not only technically challenging but extremely sensitive politically and fraught with environmental risks. The central canal will have to tunnel through the foot of the huge dyke that contains the elevated Yellow River and the western canal will have to transport water through regions susceptible to freezing. The number of people displaced by the Three Gorges Dam was 1.1 million and this water-transfer scheme is a bigger project. Moving people involuntarily is certainly potentially explosive politically. The project could also be politically explosive on the international front. One plan for the western canal calls for 'damming the Brahmaputra River and diverting 200 billion cubic metres of water annually to feed the ageing Yellow River' - a scenario that is reportedly 'giving sleepless nights to the Indian government' ('China's river plan worries India', Times of India, 23 October 2006).

Many opponents of the water-transfer project have argued that water conservation could go a long way towards addressing China's water problems because currently a tremendous amount of water is wasted ('Alert sounded over looming water shortage', The Straits Times, 10 June 2004). The most important reason for this inefficient use of water lies in the fact that 'China's farmers,

21 The National Development and Reform Commission (NDRC 2007) reported: 'The regional distribution of precipitation shows that the decrease in annual precipitation was significant in most of northern China, [the] eastern part of the north-west, and north-eastern China, averaging 20-40 mm/10a, with [the] decrease in northern China being most severe; while precipitation significantly increased in southern China and southwestern China, averaging 20-60 mm/10a...The frequency and intensity of extreme climate/weather events throughout China have experienced obvious changes during the last 50 years. Drought in northern and northeastern China, and flood in the middle and lower reaches of the Yangtze River and south-eastern China have become more severe.' 
factories and householders enjoy some of the cheapest water in the world' ('Water wastage will soon leave China high and dry', South China Morning Post, 8 March 2006), even though China's per capita endowment of water is onequarter of the world average ('Alert sounded over looming water shortage', The Straits Times, 10 June 2004).

There is, however, the unhappy possibility that neither the price mechanism nor the three canals can solve China's water problems, making its growth unsustainable unless the present mode of economic development is drastically amended.

\section{A reform agenda for avoiding crashes on the road to prosperity}

\section{Dealing with potential hardware problems}

We identified two potential hardware problems arising from the large dose of SCE-SCB-based macro-stimulus that Prime Minister, Wen Jiabao, has administered to maintain full utilisation of production capacity: NPLs that could cause either the SCBs to collapse or a fiscal crisis from the bailout of the SCBs, and lower productivity growth in the future from the crowding out of the private sector by the state sector. China's instruments of macro-stimulus have created a trade-off between maintenance of full capacity utilisation in the short run and sustenance of a high rate of capacity expansion in the long run.

Our recommendation is that China eliminates this trade-off by replacing its macro-stimulus with three new growth drivers that are interrelated: 1) creation of more new entrepreneurs; 2) urbanisation according to the principle of future homeownership; and 3) development of a modern financial system in which the private sector has a greatly enhanced role.

The State can partly offset the expanded state sector by mobilising inland migrant workers laid-off from the coastal provinces into an entrepreneurial force. Many of these migrants have sufficient work experience to start their own factories/workshops to take advantage of the increased cost competitiveness of the inland provinces created by the explosive extension of the national transportation network during the global financial crisis. Because the primary barrier to the emergence of this group of owner-operators is the availability of credit, the government should legalise small and medium private banks, as they have comparative advantage over the four large state banks in catering to the needs of these new entrepreneurs. The healthy development of the new private 
banks would require that the system of prudential supervision be strengthened and that interest rates be deregulated. Farmland should also be privatised so that the new businesses can have the collateral to access credit from the new private banks. As most of the migrants are from the western provinces, the government could unleash this first driver of growth in the western provinces on an experimental basis.

The creation of a new large group of private entrepreneurs will bring three major benefits

- expenditure by this new group will substitute for the present macro-stimulus program in keeping aggregate demand high

- private firms are likely to have higher productivity growth than SCBs

- these small and medium private enterprises will be more labour intensive than SCEs.

The second new growth driver is urbanisation based on the principle of affordable future homeownership. The fast growth of the real estate sector-not only recently but in the past decade - reflects not just speculative demand but genuine pent-up demand for housing and genuine accommodation to meet the high rate of the joint industrialisation-urbanisation process. ${ }^{22}$ The bulk of the new arrivals from the countryside cannot qualify for bank mortgages, so many investors have been buying multiple housing units to rent to new arrivals with the intention of raising the rents over time in line with the income growth of the renters. In this sense, much of the recent housing demand has been speculative.

We propose that China studies the low-cost public housing schemes in Hong Kong and Singapore and establishes a national housing program under which the new arrivals would rent homes for seven years and then have the first right to buy these units at a price based on construction costs. This 'future ownership' form of urbanisation would prevent the problem of empty housing held for speculative reasons escalating into NPLs. China can afford a massive public housing program because the expensive part of such programs in other countries is the cost of land and not the cost of the structures - and land in China is mostly owned by the State. ${ }^{23}$

22 If speculative demand had been the overwhelmingly dominant cause of the property boom, house rents would not have risen substantially (because the speculative investors would tend to rent out their extra units). Instead, rent in Beijing in March 2010 was 19.6 per cent above that in March 2009; see 'Survey shows house prices still too high', China Daily, 12 May 2010, <http://www.chinadaily.com.cn/metro/2010-05/12/ content_9839054.htm>

23 It should be noted that housing construction is relatively labour intensive and that home decoration is highly labour intensive. 
Our proposed form of urbanisation will support China's growth in three ways

- through the maintenance of real estate investment to supply the needed housing and to help maintain the existing level of aggregate demand

- through the redirection of bank loans to new rural migrants, with the new housing agency as the intermediary, to prevent the appearance of NPLs

- this housing scheme will redistribute income to the rural migrants (which helps in reducing the threat of software failure), with the positive side effect that consumption will rise to help offset the elimination of the macrostimulus program.

We note that the first and second new growth drivers are mutually reinforcing. The new enterprises of the former rural migrants would inevitably be located in or near towns and cities to take advantage of infrastructure and positive spillovers from agglomeration. We note that the main institutional adjustments that must be made to enable the working of the second new growth driver are the same as those that would help the development of the first new growth driver: privatisation of farmland, termination of the household registration system and liberalisation of the financial system.

The third interrelated new growth driver is the true legalisation of privately owned financial institutions. ${ }^{24}$ The emergence of a strong small-medium banking sector would reduce the dominance of the SCBs and hence make the economy less vulnerable to their collapse from potential NPLs. The entry of private banks (domestic and foreign) will reduce the probability that any one of the big four state banks would remain too big to fail-and hence reduce the soft-budget protection enjoyed by the now monopoly state banking system. The privatisation of some units of the SCBs, and the emergence of large domestic private banks, will also help in strengthening the budget constraints perceived by the managers of SCBs. The development of a modern banking system with a major role for the private sector will thence increase the quality of bank loans along with the increase in the quantity of bank loans - helping to reduce the appearance of NPLs along with market-directed investments replacing the macro-stimulus program. ${ }^{25}$

\section{Dealing with potential software problems}

The important realisation about hardcore poverty is that, in today's China, introducing more of the same economic policies will not produce the same

\footnotetext{
24 We do not consider listed banks in which the State holds the controlling share (often through statecontrolled intermediaries - for example, 'legal persons') to be private banks in the true sense.

25 The management of state assets and the regulation of the financial sector should also be reformed to eliminate the phenomenon of repeated recapitalisation of the SCBs.
} 
salubrious results on every front because the development problems have changed. This was illustrated above with the example that, during the first phase of economic development, the provision of more jobs (through economic deregulation) was enough to lower poverty significantly, while more recently job opportunities alone have proved insufficient.

Complicating matters is that there have not just been rising expectations about the performance of the State in its traditional functions (for example, coordinating water use); there are also new expectations about the participation of the State in some additional areas (for example, reducing income inequality). In this new situation, the greater use of democratic procedures, the establishment of an independent judiciary and the restoration of a free press might be inevitable if the CPC is to successfully accommodate the rising social expectations and mediate the emerging differences in social expectations.

One main source of recent social unrest in rural China has been the conversion of farmland to industrial parks without adequate compensation for the farmers. It is interesting therefore that the 'No. 1 Document' issued in January 2006 jointly by the CPC Central Committee and the State Council pledged to not only 'stabilise and regulate the transfer of land-use rights and accelerate land acquisition reforms', but 'expand channels to express public opinions in the countryside and improve the mechanism to resolve social conflicts' ('New pledge to give farmers a louder voice', South China Morning Post, 30 January 2007). ${ }^{26}$

The desire by the $\mathrm{Hu}$-Wen leadership to improve the institutions of governance is also borne out by the following report from the South China Morning Post about what Premier Wen said when he met a group of Chinese citizens in Japan in April 2007:

During 30 minutes of impromptu remarks, he said the key to pursuing social justice, the mainland's most important task, was to 'let people be masters of their houses and make every cadre understand that power is invested in them by the people'...Mr Wen is known for being careful about what he says, whether in prepared remarks or speaking off the cuff. The fact that he highlighted, in the presence of Hong Kong and overseas journalists, the need for political reform is uncharacteristic and interesting...There have been signs that the leadership under President $\mathrm{Hu}$ Jintao is under increasing pressure to undertake drastic political reforms to consolidate the party's grip on power and stamp out widespread corruption. ('Impromptu remarks reveal the party's pressure for reforms', South China Morning Post, 16 April 2007) 
While there are reasonable grounds for an analyst to doubt either the sincerity of Premier Wen's words or his ability to act on them, the analyst cannot doubt that Premier Wen is at least aware that democracy is one way to solve many of China's problems of governance. The embrace of the harmonious society program by the $\mathrm{Hu}$-Wen leadership reveals the CPC's acknowledgment that democracy, the rule of law, a reduction in corruption, land reform and improved income distribution make an indivisible combination that is necessary to ensure the social stability that will keep the economy on the high-growth path needed to catch up with the United States (a vision that acts as the bedrock of the CPC's legitimacy to rule).

Warding off software failure is of course much more difficult than warding off hardware failure because political reforms lie at the heart of successful reconfiguration of the software of governance. The modernisation of China's administrative software will require the adoption of free elections, a free press and an independent judiciary.

\section{Dealing with power supply failure caused by environmental degradation}

The general point is that effective policymaking on the environmental front is a very difficult task because much of the science about the problem is not known. For example, there is now persuasive evidence that China's voluminous emissions of black carbon (particles of incompletely combusted carbon) have contributed significantly to the shift to a climate pattern that produces northern droughts and southern floods of increasing intensity (Menon et al. 2002; Streets 2005). The biggest source of what has been called in the popular media the 'Asian brown cloud' is burning of coal and bio-fuels in China and India. This link between pollution and water shortages further reduces the possibility that either the price mechanism or the three canals can solve China's water problems unless the present mode of economic development is drastically amended.

China must no longer select its water strategy and it energy strategy separately. A systems approach to policymaking is necessary because the interaction among the outcomes from the different sectoral policies can generate serious unintended environmental damage. If part of the shift in China's climate is integral to global climate change, a sustainable development policy would require a complete rethinking of the location of population centres and the types of enhanced international cooperation on global environmental management.

The uncomfortable reality for China is that unless ecological balance is restored within the medium term, environmental limits could choke off further economic growth. And the uncomfortable reality for the rest of the world is that the negative consequences of large-scale environmental damage within a 
geographically large country are seldom confined within that country's borders. The continued march of China's desertification first brought more frequent sandstorms to Beijing and then, beginning in April 2001, sent yellow dust clouds not only across the sea to Japan and Korea but across the ocean to the United States. China's environmental management is a concern not only for China's welfare but for global welfare.

In discussing the environmental aspects of the water-transfer plan, it is important to note that there is now open controversy in China involving a key government infrastructure project - and this controversy is not limited to members of the technocracy. The very public nature of the controversy - and the involvement of more than just scientists, engineers and economists in it - reveals how very far social attitudes have progressed. The important point is that this change in social expectations will require any government in China to live in harmony with nature. Any government will, however, have great difficulties in doing so even if it wants to because a green growth policy involves a systems approach, and scientific understanding of many ecological subsystems and the nature of their interactions is still rather incomplete.

The global environment is an important area in which China can help to build a harmonious world system. ${ }^{27}$ Specifically, China should be mobilising international consensus to form an international research consortium to develop ways to burn coal cleanly because China is now building a power station a week and hence is able to facilitate extensive experimentation on prototype plants to burn coal cleanly. Furthermore, given the growing water shortages in China (especially in the north) and in many of its neighbouring countries, China should start a regional forum on the joint use of water from the Tibetan Plateau before the situation becomes too critical. China should also be mobilising an international scientific research effort on the desalination of seawater for drinking. If global cooperation on clean energy research and desalination research is successful, it will unleash sustainable development in the whole world.

\section{Dealing with power supply failure caused by trade protectionism}

Finally, we consider briefly how to reduce the probability of the speeding car (that is, China) crashing into a roadblock that takes the form of trade protectionism. There is no denying that international tensions over China's large chronic trade surpluses have increased greatly since 2004, and have been exacerbated by the global financial crisis. China has been accused of misconduct on many international fronts - for example, causing the global financial crisis by

27 See McKibbin et al. (2008) for an example of an efficient global carbon dioxide emission compact that China and the rest of the world could adopt. 
forcing cheap loans on US consumers ${ }^{28}$ and engaging in beggar-thy-neighbour devaluations by keeping a fixed renminbi-US dollar exchange rate ('Will China listen?', The New York Times, 17 March 2010).

The root of China's chronic current account surplus is that the sum of savings by SCEs and the private sector exceeds the sum of their investment expenditures. This chronic large trade surplus reveals a deep-seated and serious problem in China's economy: its dysfunctional financial system (Liu and Woo 1994). China generates the current account surplus because of inadequate financial intermediation and the surplus grows over time because the dysfunctional financial system fails to pool risks to reduce uncertainty-induced savings and fails to provide loans to reduce investment-motivated saving. The optimal solution to China's excess saving is to establish an improved intermediation mechanism for coordinating private savings and private investments.

It must be mentioned in fairness, however, that a trade imbalance reflects the economic situation in two countries: China could not have over-saved if the United States had not under-saved. US profligacy is to be blamed for the trade tensions just as much as Chinese thriftiness. Furthermore, as Woo (2008) has pointed out, even if China's trade balance were zero, the pains of structural adjustment and income redistribution caused by technological innovations in the United States, institutional changes in the United States, globalisation and immigration into the United States would still be there - and the amount of US worker anxiety generated collectively would be much larger than the additional worker anxiety generated by the widening trade deficit.

The reduction of trade tensions between the United States and China would be helped if the United States now strengthened its social safety nets to lower the cost of changing jobs. Specifically, the US Congress should speed up the reduction of fiscal imbalances and expand trade adjustment programs - especially those that upgrade the skills of younger workers. The important point is that USChina trade tensions would be lower if both countries undertook corrective policies rather than if China acted alone.

Apart from what the United States and China can each do independently to reduce international tensions over the trade imbalance, they should also work together to prevent the General Agreement on Tariffs and Trade (GATT)-WTO free-trade regime from weakening. Specifically, China has benefited immensely from the WTO system, yet it has, up to this point, played a very passive role

\footnotetext{
28 Nicholas Lardy has described China as being in a co-dependent relationship with the United States in which ' $[t]$ he United States is the addict. We are addicted to consumption. China is the dealer. They're supplying the credit that makes it possible for us to over-consume' ('Winter Institute: China and US joined at the hip', News release, 2 March 2009, From conference at St Cloud State University, Minnesota, 27 February 2009, <http://www.stcloudstate.edu/news/pressreleases/default.asp?storyID=28126>).
} 
in pushing the Doha Round of negotiations forward to completion. By default, Brazil and India have assumed the leadership of the developing economies' camp in the trade negotiations. According to Susan Schwab, the US Trade Representative at the Group of Four (G4: the United States, European Union, Brazil and India) meeting in Potsdam in June 2007, Brazil and India retreated from their earlier offers to reduce their manufacturing tariffs in return for cuts in agricultural subsides by the industrialised economies because of 'their fear of growing Chinese imports' ('Schwab surprised by stance of India and Brazil' and 'China's shadow looms over Doha failure', Financial Times, 22 June 2007).

With the United States weakening in its resolve to protect the multilateral freetrade system (Woo 2008), China should now become more active in the Doha Round negotiations to deregulate world trade further. Such a role will be very much in China's interest because Brazil is now bypassing multilateral trade liberalisation by entering into free-trade negotiations with the European Union. The fact is that a growing number of nations such as Brazil 'are increasingly wary of a multilateral deal because it would mandate tariff cuts, exposing them more deeply to low-cost competition from China. Instead, they are seeking bilateral deals with rich countries that are tailored to the two parties' needs' ('Brazil, others push outside Doha for trade pacts', The Wall Street Journal, 5 July 2007). It is time for China to show that it is a responsible stakeholder by joining in the stewardship of the multilateral free-trade system. Such an international stance would also reduce the threat of this type of power supply failure to China's own growth.

\section{Conclusions}

Our assessment is that the probabilities of either a software failure or a power supply failure are higher than the probability of a hardware failure because the first two are harder problems to deal with. For most hardware problems, China can learn from the experiences of the rest of the world, especially those of the richer countries in East Asia, as long as ideological constraints on methods of economic management continue to wither. The 1868 insight of the Meiji reformists that success in economic catch-up largely involves willingness to adopt and adapt to 'best international practices' will continue to apply to China until its per capita GDP converges with that of Japan and Western Europe.

Dealing with software failure is harder than dealing with hardware failure for two major reasons. The first is that development policymaking in China has become more challenging because popular expectations of administrative performance have risen dramatically with income growth and, more importantly, with increasing knowledge of the outside world. A Chinese government that 
consistently fails to produce results in line with the rise in social expectations runs the increasing risk of being challenged by internal factions within the CPC, culminating in an open split, with each side seeking the support of non-party groups.

The second reason is that successful reconfiguration of the administrative software requires not just highly developed political skills but favourable circumstances in the domestic political arena and a benign international environment - both of which are normally beyond the reach of most politicians to manipulate. What happens in the future will depend on whether the CPC is sufficiently confident and politically skilful enough to lead the democratic transition and emerge afterwards as the most important political force. History tells us that the French and British monarchies reacted very differently to popular requests for reform of the administrative software - and the outcomes were very different in each case. The practical issue is whether the CPC can do a better job in political transition than the Kuomintang did in Taiwan during the period 1983-88.

Dealing with power supply problems is much harder than dealing with hardware problems because it often involves working on issues of which the world has few (mostly, no) successful experiences (for example, a global carbon dioxide emission pact) or it involves working with powerful foreign partners where differentiation between cultural misunderstanding (for example, a bombastic national but nevertheless well-meaning demeanour) and unstated national rivalry (for example, keeping shipping lanes open) is not easy-or it involves working with both of these difficult conditions. As most solutions to power supply failures require a high degree of mobilisation of international effortwhich China has historically been too weak to participate in meaningfully-

China and the other major powers will need to converge in their rethinking of China's responsibilities in the world economy before there can be significant cooperation on common problems. ${ }^{29}$

29 A timely discussion about China's role in the future world economy is found in the collection of papers in Garnaut et al. (2009) - for example, Woo (2009). The present dispute between China and its biggest trading partners over its exchange-rate regime illustrates very well the difficulties of handling a power supply problem. The proposed - and highly contentious - solution of a significant renminbi appreciation is typical of the narrowly focused solutions that have been proposed for power supply failures (for example, only building canals to transfer water from south to north when China should also reduce black carbon and concentrate urbanisation in southern China). Specifically, an economically more efficient - and politically more amicablesolution to the trade imbalance problem would require: 1) more than one policy instrument to be used to reduce the trade imbalance (that is, not just appreciation of the renminbi, but, at least, liberalisation of the Chinese government's procurement policy and export promotion by the United States); 2) more than one party to adjust its policies when the situation is the product of policies in at least two countries (that is, the United States and China must take corrective policies, not just China); and 3) more than the pursuit of a single policy target but achievement of a range of more direct welfare objectives as well (that is, going beyond reduction in the size of China's trade surplus to include objectives such as strengthening the WTO system of adjudication, and keeping GDP growth rates high in all countries). 
China's economy has now become an important shaping force of the global economy and, along with it. Chinese civil society has come to possess more and more of the middle-class aspirations common in the industrialised world. China's continued high growth now necessitates a new development strategy that also emphasises the creation of a harmonious society and a harmonious world - and this will require an improvement in its administrative software and the sustenance of the global power supply.

\section{References}

Asian Development Bank (ADB) 2007, Key Indicators: Inequality in Asia, Asian Development Bank, Manila.

Becker, Jasper, 2003, "The death of China's rivers," Asian Times Online, August 26.

Chang, G. G. 2001, The Coming Collapse of China, Random House, New York.

Démurger, S., Sachs, J. D., Woo, W. T., Bao, S., Chang, G. and Mellinger, A. 2002, 'Geography, economic policy and regional development in China', Asian Economic Papers, vol. 1, no. 1 (Winter), pp. 146-97.

Economy, E. C., 2004, The River Runs Black: The environmental challenge to China's future, Cornell University Press, Ithaca, NY.

Forsythe, M. 2009, 'Is China's economy speeding off the rails?', The New York Times, 23 December 2009.

Garnaut, R., Song, L. and Woo, W. T. (eds) 2009, China's New Place in a World in Crisis: Economic, geopolitical and environmental dimensions, ANU E Press and Brookings Institution Press, Canberra and Washington, DC.

Lardy, N. R. 1998, China's Unfinished Economic Revolution, Brookings Institution Press, Washington, DC.

Liu, L.-Y. and Woo, W. T. 1994, 'Saving behavior under imperfect financial markets and the current account consequences', Economic Journal, vol. 104, no. 424 (May), pp. 512-27.

McKibbin, W. J. and Woo, W. T. 2003, 'The consequences of China's WTO accession on its neighbours', Asian Economic Papers, vol. 2, no. 2 (Spring/ Summer), pp. 1-38.

McKibbin, W. J., Wilcoxen, P. J. and Woo, W. T. 2008, 'China can grow and help prevent the tragedy of the CO2 commons', in L. Song and W. T. Woo (eds), 
China's Dilemma: Economic growth, the environment and climate change, Asia Pacific Press and Brookings Institution Press, Canberra and Washington, DC, pp. 190-225.

Menon, S., Hansen, J., Nazarenko, L. and Luo, Y. 2002, 'Climate effects of black carbon in China and India', Science, vol. 297, no. 27 (September), pp. 2250-3.

National Development and Reform Commission (NDRC) 2007, China's National Climate Change Programme, June, National Development and Reform Commission, Beijing.

O'Neill, J., Wilson, D., Roopa, P. and Stupnytska, A. 2005, How solid are the BRICs?, Global Economics Paper No. 134, 15 December, Goldman Sachs, New York.

Sachs, J. D. and Woo, W. T. 2000, 'Understanding China's economic performance', Journal of Policy Reform, vol. 4, no. 1, pp. 1-50.

Shih, Victor, 2010, "China's 8,000 Credit Risks," The Wall Street Journal, February 8, 2010.

Streets, D. 2005, 'Black smoke in China and its climate effects', Asian Economic Papers, vol. 4, no. 2 (Spring/Summer), pp. 1-23.

Tong, J. and Woo, W. T. 2006, 'Keeping fiscal policy sustainable in China', in R. Garnaut and L. Song (eds), The Turning Point in China's Economic Development, Asia Pacific Press, Canberra.

Woo, W. T. 2001, 'Recent claims of China's economic exceptionalism: reflections inspired by WTO accession', China Economic Review, vol. 12, nos 2-3, pp. 107-36.

Woo, W. T. 2006, 'The structural nature of internal and external imbalances in China', Journal of Chinese Economic and Business Studies, vol. 4, no. 1 (February), pp. 1-20.

Woo, W. T. 2008, 'Understanding the sources of friction in US-China trade relations: the exchange rate debate diverts attention away from optimum adjustment', Asian Economic Papers, vol. 7, no. 3 (Fall), pp. 65-99.

Woo, W. T. 2009, 'China and international financial reform', in R. Garnaut, L. Song and W. T. Woo (eds), China's New Place in a World in Crisis: Economic, geopolitical and environmental dimensions, ANU E Press and Brookings Institution Press, Canberra and Washington, DC, pp. 15-32. 
Woo, W. T. and Xiao, G. 2007, 'Facing protectionism generated by trade disputes: China's post-WTO blues', in R. Garnaut and L. Song (eds), China: Linking markets for growth, Asia Pacific Press, Canberra.

Woo, W. T., Li, S., Yue, X., Wu, H. X. and Xu, X. 2004, The poverty challenge for China in the new millennium, Report to the Poverty Reduction Taskforce of the Millennium Development Goals Project of the United Nations, United Nations, New York. 